\title{
Diarréia e rotavírus
}

Diarrhea and rotavirus

Instituto Adolfo Lutz e Centro de Vigilância Epidemiológica "Professor Alexandre Vranjac"

\begin{abstract}
A doença diarréica é uma das doenças mais comuns em crianças em todo o mundo. Embora as evidências demonstrem o declínio da mortalidade nessa última década, em algumas áreas subdesenvolvidas a diarréia permanece uma das principais causas de morte em crianças menores de dois anos de idade. A morbidade associada à diarréia também é importante; crianças são acometidas por um a 10 episódios de diarréia anuais. Em países desenvolvidos, assim como no Brasil, sua importância está relacionada ao impacto da doença na população, traduzido pelos seus danos à saúde, afetando o desenvolvimento infantil, bem como à sociedade pelos custos gerados pela demanda aos serviços médicos, atendimento ambulatorial, pronto atendimento, hospitalizações (custos diretos) e as perdas de dias de trabalhos, de escola, gastos com medicamentos, transportes, etc. (custos indiretos). Adicionalmente, o conhecimento da interação de diarréia persistente e má nutrição como causa de mortalidade tem reforçado a necessidade de desenvolvimento de programas de intervenção além do tratamento baseado em terapia de reidratação oral.
\end{abstract}

A etiologia das diarréias pode envolver vários agentes como vírus, bactérias e parasitas. Os agentes bacterianos são relativamente mais importantes em países em desenvolvimento, enquanto os agentes virais são mais relevantes em países industrializados. A importância desses agentes está relacionada às condições de higiene e saneamento básico da população.

Os rotavírus são reconhecidamente os agentes virais mais importantes associados às doenças diarréicas agudas, atingindo humanos e várias espécies de mamíferos e aves. Infecções por rotavírus são comuns em muitas dessas espécies e muitas vezes podem ocorrer de forma subclínica. Os episódios de diarréia podem variar de um quadro leve, com diarréia líquida e duração limitada a quadros graves com febre, vômitos e desidratação. As consequiências da infecção estão relacionadas à idade. Embora possam infectar indivíduos e animais de todas as idades, infecções sintomáticas, isto é, diarréia, geralmente ocorrem em crianças na faixa etária de seis meses a dois anos. Tem sido a principal causa de surtos de diarréia nosocomial e em creches e pré-escolas. Apesar da doença diarréica ocorrer primariamente em crianças, também é comum em jovens e adultos, associada a surtos esporádicos de diarréia em espaços fechados como escolas, ambientes de trabalho e hospitais.

Anualmente, estimam-se 130 milhões de casos de diarréia por rotavírus, com 500 mil mortes de crianças abaixo de cinco anos de idade e dois milhões de hospitalizações. Nos países em desenvolvimento cerca de 1.205 crianças morrem diariamente de diarréia por rotavírus. Embora os casos de diarréia por rotavírus se concentrem em crianças de países em desenvolvimento, esse vírus distribui-se universalmente, infectando todas as crianças no mundo, de distintas classes sociais.

Os rotavírus, eliminados em grande concentração nas fezes infectadas, são transmitidos pela via fecal-oral, por água, alimentos e objetos contaminados, por pessoa a pessoa e, provavelmente, secreções respiratórias, mecanismos que permitem a disseminação explosiva da doença.

Devido ao elevado índice de morbi-mortalidade associada à diarréia por rotavírus, ficou evidente a necessidade de medidas urgentes como o desenvolvimento de vacinas contra esse vírus, cujo objetivo principal é a atenuação da gravidade da doença diarréica.

O rotavírus pertence à família REOVIRIDAE. A partícula viral completa é composta por triplo capsídeo protéico contendo o genoma de RNA de fita dupla segmentado, que codifica proteínas estruturais e não estruturais. As principais proteínas estruturais - VP4, VP6 e VP7 - atuam como antígenos na indução de anticorpos neutralizantes, provocando resposta imune protetora, e formam a base da classificação atual dos rotavírus em grupos (A-H), e em genótipos/sorotipos P (VP4) e G (VP7). Os genótipos são determinados por métodos moleculares, enquanto os sorotipos, por métodos de neutralização. A detecção dos rotavírus do grupo A pode ser realizada através de reações imunoenzimáticas, em ensaios de captura de antígeno diretamente do material fecal, empregando-se vários kits comerciais desenvolvidos para o diagnóstico rápido.

Devido à dificuldade na propagação desses vírus em culturas celulares e, conseqüentemente, à dificuldade em produzir reagentes sorotipos específicos, grande ênfase foi dada na análise do genoma viral. Com o avanço das técnicas de biologia molecular e a disponibilidade de dados da seqüência de vários sorotipos de rotavírus, foram desenvolvidos ensaios moleculares de Reação de Polimerase em Cadeia (PCR) empregando-se primers específicos. Essas técnicas de genotipagem têm gerado importantes informações sobre a epidemiologia molecular dos rotavírus.

\footnotetext{
Correspondência para/ Correspondence to: *Texto de difusão técnico-científica da Secretaria de Estado da Saúde de São Paulo. 
Até o momento foram identificados $10 \mathrm{G}$ (VP7) e 9 P (VP4) tipos de rotavírus humanos. Os tipos G1 a G4 são os mais comuns e para os quais estão sendo desenvolvidas vacinas; os tipos G8 e G12 são raramente encontrados. O tipo G9 é prevalente na Índia, ocorrendo em vários países a partir do final da década de 90 . Os rotavírus tipos G6 e G10, que eram exclusivamente patógenos bovinos, foram detectados em crianças com diarréia. O tipo G5, reconhecido como patógeno em suínos em vários países, foi pela primeira vez encontrado em amostras de fezes diarréicas de crianças brasileiras.

\section{Rotavírus no Brasil}

Na década de 80, foi implantada rede de laboratórios em oito Estados e no Distrito Federal para o estudo da diarréia por rotavírus no Brasil. Os dados obtidos demonstraram que a freqüência desse agente variou entre $13 \%$ a $20 \%$ nos diferentes Estados. Em nosso País a sazonalidade é variável, com aumento na incidência dos rotavírus nos meses mais frios ou no período de seca, entre maio e setembro, nos Estados das regiões Central e Sudeste. Por outro lado, no Norte e Nordeste a ocorrência de rotavírus se distribui durante todo o ano.

Estudos realizados nos últimos dez anos no Brasil mostraram a circulação dos tipos mais comuns de rotavírus $(G 1, G 2$, G3, G4 e P[4], P[6] e P[8]), observando-se maior incidência de rotavírus tipo G1P[8] e a emergência do tipo G9, a partir de 1998.Foram detectados tipos incomuns de rotavírus em amostras humanas, como rotavírus G5 e P[3], e misturas de tipos de rotavírus em uma mesma amostra. A presença de múltiplos tipos $\mathrm{G}$ e/ou $\mathrm{P}$ nas amostras, consistente com infecções com mais do que um tipo de rotavírus, aumenta a chance de rearranjos genéticos durante infecções naturais.

A monitoração contínua dos genótipos circulantes na população é importante para o futuro desenvolvimento de uma vacina contra a doença por rotavírus, como também para detecção de rotavirus "reassortants", após a introdução da vacina.

\section{Surto de diarréia por rotavírus}

Desde o início da década de 90 foi enfatizada a investigação de surtos de doenças de transmissão hídrica e alimentar de notificação compulsória, no Estado de São Paulo. Com a re-emergência da cólera, foi implantado no território nacional o Programa de Monitoração da Doença Diarréica Aguda (MDDA), para a detecção precoce de surtos de diarréia.

De maio a outubro de 2004 foi observado aumento nos casos de diarréia aguda em São Paulo, sendo notificados ao Centro de Vigilância Epidemiológica 2.364 casos suspeitos de diarréia por rotavírus. No mesmo período, o Laboratório de Vírus Entéricos do Instituto Adolfo Lutz, referência macro-regional para rotavírus, recebeu 753 amostras de fezes de pacientes com sintomatologia diarréica provenientes de surtos em diversos municípios.

Para o diagnóstico laboratorial do rotavírus foram utilizadas metodologias de ensaio imunoenzimático (EIE) para detecção de antígeno, eletroforese em gel de poliacrilamida (EGPA) para análise do genoma viral e PCR para genotipagem.
Observando a distribuição dos casos confirmados de diarréia por rotavírus desde o início deste ano, verificamos a ocorrência de positividade para rotavírus a partir de maio, com pico no mês de setembro e declínio em outubro. O rotavírus foi detectado em $42,2 \%$ do total das amostras analisadas no período de maio a outubro, sendo que os tipos G1 e G9 foram os mais freqüentes.

A diarréia por rotavírus foi diagnosticada principalmente em crianças menores de cinco anos de idade, com pico de ocorrência entre os sete a 12 meses. A infecção por esse vírus também atingiu crianças jovens, adultos e idosos.

As informações obtidas estão sendo analisadas para a caracterização epidemiológica do surto.

\section{Notificação}

A notificação de surtos de diarréia aguda é de extrema relevância para desencadear uma investigação minuciosa quanto a sua origem, se em domicílios, creches, escolas, hospitais, ou devido a problemas ambientais, para se conhecer as possíveis causas de transmissão para que medidas eficazes de controle possam ser adotadas o mais precocemente possível. É também importante lembrar que a identificação de um caso de rotavírus merece a busca ativa de outros casos, pois pode estar relacionado a possíveis surtos.

As orientações para a população em relação aos cuidados com a criança com diarréia por rotavírus são os mesmos para as diarréias em geral, lembrando que os casos podem ser mais graves nas menores de dois anos. Mães de crianças com início de sintomas de diarréia ou vômitos devem ser orientadas para oferecer imediatamente soro caseiro ou sais hidratantes e água tratada, para prevenir a desidratação. Não suspender alimentação e procurar imediatamente o serviço médico para o tratamento adequado.

Devido à importância epidemiológica dos rotavírus nas diarréias graves, inúmeros esforços têm sido realizados na elaboração de uma vacina eficaz para o combate da doença. O desenvolvimento da vacina de rotavírus foi ajustado para a distribuição de cepas de vírus vivos, atenuadas, por via oral. Atualmente, várias vacinas estão sendo desenvolvidas e testadas dentro do Programa de Vacina de Rotavírus da PATH - Program for Appropriate Technologies in Health. Testes vacinais para demonstrar a eficácia dessas vacinas deixaram claro que a meta é prevenir a diarréia grave, que pode levar à desidratação, reduzindo a morbidade e a mortalidade infantil.

O conhecimento da distribuição dos tipos de rotavírus na população é importante como subsidio para as estratégias de desenvolvimento de vacinas. Os resultados obtidos em trabalhos no Brasil, em contraste com outros países, demonstram que as infecções humanas por rotavírus são peculiares, apresentando alta frequiência de infecções mistas, tipos incomuns, além dos tipos mundialmente distribuídos. Estudos epidemiológicos mais abrangentes são necessários para a futura inclusão de novos genótipos/sorotipos nas vacinas a serem introduzidas no Brasil. 